\title{
An Inverse Agonist Ligand of the PTH Receptor Partially Rescues Skeletal Defects in a Mouse Model of Jansen's Metaphyseal Chondrodysplasia
}

\author{
Hiroshi Noda, ${ }^{1}$ Jun Guo, ${ }^{1}$ Ashok Khatri, ${ }^{1}$ Thomas Dean, ${ }^{1}$ Monica Reyes, ${ }^{1}$ Michael Armanini, ${ }^{1}, 2,3$ \\ Daniel J Brooks, ${ }^{1,2,3}$ Janaina S Martins, ${ }^{1}$ Ernestina Schipani, ${ }^{4}$ Mary L Bouxsein, ${ }^{1,2,3}$ Marie B Demay, ${ }^{1}$ \\ John T Potts Jr, ${ }^{1}$ Harald Jüppner, ${ }^{1}$ and Thomas J Gardella ${ }^{1}$ (D) \\ ${ }^{1}$ Endocrine Unit, Massachusetts General Hospital, and Harvard Medical School, Boston, MA, USA \\ ${ }^{2}$ Department of Orthopedic Surgery, Harvard Medical School, Boston, MA, USA \\ ${ }^{3}$ Center for Advanced Orthopedic Studies, Beth Israel Deaconess Medical Center, Boston, MA, USA \\ ${ }^{4}$ University of Michigan, Ann Arbor, MI, USA
}

\begin{abstract}
Jansen's metaphyseal chondrodysplasia (JMC) is a rare disease of bone and mineral ion physiology that is caused by activating mutations in PTHR1. Ligand-independent signaling by the mutant receptors in cells of bone and kidney results in abnormal skeletal growth, excessive bone turnover, and chronic hypercalcemia and hyperphosphaturia. Clinical features further include short stature, limb deformities, nephrocalcinosis, and progressive losses in kidney function. There is no effective treatment option available for JMC. In previous cell-based assays, we found that certain N-terminally truncated PTH and PTHrP antagonist peptides function as inverse agonists and thus can reduce the high rates of basal CAMP signaling exhibited by the mutant PTHR1s of JMC in vitro. Here we explored whether one such inverse agonist ligand, $\left[\mathrm{Leu}^{11}, \mathrm{dTrp}{ }^{12}, \operatorname{Trp}^{23}, \mathrm{Tyr}^{36}\right]-\mathrm{PTHrP}(7-36) \mathrm{NH}_{2}(\mathrm{IA})$, can be effective in vivo and thus ameliorate the skeletal abnormalities that occur in transgenic mice expressing the PTHR1-H223R allele of JMC in osteoblastic cells via the collagen-1 $\alpha 1$ promoter (C1HR mice). We observed that after 2 weeks of twice-daily injection and relative to vehicle controls, the IA analog resulted in significant improvements in key skeletal parameters that characterize the $\mathrm{C} 1 \mathrm{HR}$ mice, because it reduced the excess trabecular bone mass, bone marrow fibrosis, and levels of bone turnover markers in blood and urine. The overall findings provide proof-of-concept support for the notion that inverse agonist ligands targeted to the mutant PTHR1 variants of JMC can have efficacy in vivo. Further studies of such PTHR1 ligand analogs could help open paths toward the first treatment option for this debilitating skeletal disorder. (c) 2019 American Society for Bone and Mineral Research.
\end{abstract}

KEY WORDS: CELL/TISSUE SIGNALING - ENDOCRINE PATHWAYS; PTH/VIT D/FGF23; ANIMAL MODELS; GENETIC ANIMAL MODELS; THERAPEUTICS HORMONE REPLACEMENT/RECEPTOR MODULATORS

\section{Introduction}

ansen's metaphyseal chondrodysplasia $(\mathrm{JMC})^{(1)}$ is a rare disorder of bone and mineral ion physiology caused by activating mutations in parathyroid hormone receptor-1 (PTHR1). ${ }^{(2)}$ Clinical hallmarks of the disease include short stature, deformed, undermineralized bones, chronic hypercalcemia and hyperphosphaturia with normal serum PTH levels, and elevated serum markers of bone turnover. ${ }^{(3-7)}$ Disease features become apparent within days or months after birth and progress with age. $(6,7)$ The overall disease profile is consistent with the critical roles that the PTHR1 plays in endochondral bone formation, ${ }^{(8)}$ and in calcium and phosphate homeostasis; processes that are normally controlled by the two endogenous peptide ligands, PTH-related protein (PTHrP) and PTH, respectively. ${ }^{(9)}$ There is currently no effective treatment option available for JMC patients.

PTHR1 is a family B G-protein-coupled receptor (GPCR) and, as for each of these receptors, binds its agonist peptide ligands, such as the bioactive PTH(1-34) fragment, via a two-site mechanism. This mechanism involves an initial docking of the (15-34) portion of the ligand to the amino-terminal extracellular domain (ECD) portion of the receptor and a subsequent engagement of the N-terminal (1-14) portion of the ligand with the extracellular loop and seven-transmembrane helical domain (TMD) region of the receptor, which leads to receptor activation. ${ }^{(10,11)}$ The recent high-resolution X-ray crystal $^{(12)}$ and cryogenic electron

Received in original form March 15, 2019; revised form October 14, 2019; accepted October 24, 2019. Accepted manuscript online November 5, 2019. Address correspondence to: Thomas J Gardella, PhD, Endocrine Unit Massachusetts General Hospital, Thier 1025, 50 Blossom St, Boston, MA 02474, USA. E-mail: gardella@helix.mgh.harvard.edu

Additional Supporting Information may be found in the online version of this article.

Current address: Hiroshi Noda, Research Division, Chugai Pharmaceutical Co., Ltd., Shizuoka 4128513, Japan.

Journal of Bone and Mineral Research, Vol. 35, No. 3, March 2020, pp 540-549.

DOI: $10.1002 / j b m r .3913$

C 2019 American Society for Bone and Mineral Research 
microscopy (cryo-EM) ${ }^{(13)}$ structures of the PTHR1, each in complex with a $\mathrm{PTH}(1-34)$ or $\mathrm{PTHrP}(1-36)$ analog ligand, confirm and extend this model of ligand binding. These structures thus show the peptide to be bound as a linear $\alpha$-helix with its $C$ terminal portion docked to the ECD and its $\mathrm{N}$-terminal portion projecting into the core of the TMD bundle. This binding mode is similar to that seen in the high-resolution structures reported for several other family B GPCRs, including the receptors for glucagon, GLP-1, and calcitonin, each in complex with a bound peptide ligand, ${ }^{(14-18)}$ thus supporting a common basic mechanism of ligand-induced activation used by each of the family B GPCRs.

All of the known mutations that cause JMC map to one of three residue positions in PTHR1, each of which is located at the cytosolic base of a TMD helix: His223 in TM helix (TM) 2, Thr410 in TM6, and lle458 in TM7. ${ }^{(2,19)}$ The residues at these positions are highly conserved in the family B GPCRs. The PTHR1 mutations of JMC can thus be predicted to perturb a critical component of the receptor located in the lower portion of the TMD bundle that controls receptor activation and deactivation. ${ }^{(11-13,20)}$

Inverse agonists are a subclass of antagonist ligands that can bind to an active-state receptor and revert it to an inactive conformation. ${ }^{(21-23)}$ A number of competitive antagonist ligands for the PTHR1 developed from the PTH(7-34) or PTHrP(7-36) fragments ${ }^{(24-26)}$ have been shown to function as inverse agonists in vitro and can thus suppress the basal rates of CAMP signaling in transfected COS-7 or HEK293 cells expressing a PTHR1 variant of JMC. ${ }^{(27-29)}$ Here, we explore the hypothesis that such an inverse agonist analog can be effective on a PTHR1 mutant of JMC in vivo. We thus assessed the capacity of [Leu ${ }^{11}, \mathrm{dTrp}{ }^{12}$, $\operatorname{Trp}^{23}{ }^{23} \mathrm{Tyr}^{36}$ ]-PTHrP(7-36) $\mathrm{NH}_{2}$, a peptide shown to act as a potent inverse agonist in vitro, ${ }^{(28,29)}$ to rescue the skeletal abnormalities that occur in transgenic mice expressing the PTHR1-H223R allele of JMC in osteoblasts. ${ }^{(30)}$ These mice exhibit a marked skeletal phenotype characterized principally by excess bone mineral density in the marrow compartments. Although the inverse agonist treatment did not completely reverse the mutant phenotype, we did observe, with only 2 weeks of intermittent dosing, significant improvements in a number of the key features of the mutant skeletal phenotype.

\section{Materials and Methods}

Peptides, cells and reagents

The peptides [ $\left[\mathrm{Leu}^{11}, \mathrm{dTrp}{ }^{12}, \operatorname{Trp}^{23}, \mathrm{Tyr}^{36}\right]$-hPTHrP(7-36)NH ${ }_{2}{ }^{(28)}$ and $\left[d \operatorname{Trp}^{12}, \mathrm{Nle}^{8,18,} \mathrm{Tyr}^{34}\right.$ ]-bPTH(7-34) $\mathrm{NH}_{2}{ }^{(25)}$ and hPTH(1-34) $\mathrm{NH}_{2}$ \{PTH(1-34)\} were synthesized by the Massachusetts General Hospital Biopolymer Core facility. Peptides were HPLC-purified and confirmed by mass spectroscopy. GHR-10 cells ${ }^{(29)}$ are derived from HEK293 cells by stable transfection to expresses the luciferase-based pGlosensor-22F (GloSensor ${ }^{\circledR}$; Promega, San Luis Obispo, CA, USA) CAMP reporter and the PTHR1-H223R mutant allele of JMC.

\section{Functional assessment of inverse agonism in cultured cells}

GHR-10 cells were seeded into white, clear-bottomed 96-well plates and used for assay 24 to 48 hours after the cell monolayers became confluent. For assay, the cells were preloaded with luciferin for $20 \mathrm{~min}$ at room temperature in $\mathrm{CO}_{2}$-independent media (ThermoFisher Scientific, Waltham, MA, USA) and then treated with ligand at varying concentrations in media or media alone and luminescence was measured at 2-min intervals using a
PerkinElmer Envision plate reader. For dose-response curves, the area-under-the-curve (AUC) of the time course-luminescence response at each ligand concentration was expressed as a percent of the response observed in the absence of ligand and plotted versus ligand concentration. Data from three independent experiments with duplicate wells in each were combined as means $\pm S D$.

\section{Mouse breeding and maintenance}

Collagen1a1-PTHR1-H223R transgenic (C1HR) mice ${ }^{(30)}$ in strain FVB were maintained by mating heterozygous $\mathrm{C} 1 \mathrm{HR}$ males to wild-type FVB females (Charles River Laboratories, Worcester, MA, USA; cat \#207FVB). Genotypes were determined by PCR of genomic DNA obtained from tail tissue using $5^{\prime}$-GAGTCTACATGTCTAGGGTCTA- $3^{\prime}$ and 5'-TAGTTGGCCCACGTCCTGT- $3^{\prime}$ as forward and reverse primers, respectively. The mice were housed in facilities operated by the Center for Comparative Medicine of the Massachusetts General Hospital, and all experimental procedures were approved by the MGH Institutional Animal Care and Use Committee and in compliance with federal, state, and local animal care rules and guidelines. C1HR mice and wild-type littermates were maintained on normal chow with a soft diet supplement (DietGel 76A plus DietGel Boost; Clear H2O, Portland, ME, USA), which was provided due to the oversized incisors in the C1HR mice. Heterozygous C1HR mice and wild-type littermate controls were assigned randomly to treatment groups. Power calculations predicted that the number of animals used per study group would be sufficient to detect statistically significant differences in intended primary experimental outcomes (ie, changes in bone structural and cellular parameters, blood and urine markers, and mRNA levels). ${ }^{(30,31)}$

\section{Peptide preparation and injection}

A stock solution of $\left[\right.$ Leu $\left.^{11}, \mathrm{dTrp}^{12}, \operatorname{Trp}^{23}, \mathrm{Tyr}^{36}\right]-\mathrm{PTHrP}(7-36) \mathrm{NH}_{2}$ was prepared in $10 \mathrm{mM}$ acetic acid at a peptide concentration of $2.0 \times 10^{-3} \mathrm{M}$. For injection, the stock solution was diluted in vehicle $(150 \mathrm{mM} \mathrm{NaCl}, 10 \mathrm{mM}$ citrate, $0.05 \%$ Tween $80, \mathrm{pH} 5.0)$ to a peptide concentration of $2.0 \times 10^{-4} \mathrm{M}$. Mice were injected twice daily (BID) subcutaneously into the interscapular area with each injection at a peptide dose of $500 \mathrm{nmol}(1.9 \mathrm{mg}) / \mathrm{kg}$ body weight. The injection volume was $2.5 \mathrm{~mL} / \mathrm{kg}$, corresponding to 10 to $26 \mu \mathrm{L}$ per mouse, depending on body weight, which, at age 24 days, was $12.9 \pm 1.3 \mathrm{~g}(n=17)$ and $6.8 \pm 0.8 \mathrm{~g}(n=19$; mean \pm SD) for wild-type and C1HR mice, respectively. The peptide injection dose was selected to be as high as practical given limits of peptide solubility $(\sim 7.0 \mathrm{mg} / \mathrm{mL})$, the expected rapid rate of clearance of the peptide from the circulation, ${ }^{(24)}$ a rapid rate of dissociation from the receptor, ${ }^{(28)}$ and the goal of achieving as close to maximum occupancy of the mutant receptor as possible. In prior studies, we found that injection of PTH(1-34) at a dose of $50 \mathrm{nmol} / \mathrm{kg}$ into wild-type mice was sufficient to induce a frank hypercalcemic response, ${ }^{(32)}$ indicating effective ligand occupancy of the PTHR1 in target tissue. We thus predicted at least some occupancy of the mutant PTHR1-H223R would be achieved by the current inverse agonist peptide when injected at a 10-fold higher dose than used in the prior study for PTH (1-34). Control animals were injected with vehicle at the same injection volume $(2.5 \mathrm{~mL} / \mathrm{kg})$. Mice were injected for 17 days at approximately 12-hour intervals beginning at 7 days of age. At 12 hours after the last injection, the mice were euthanized, and tissue samples were dissected for analysis. 
To double-label the bone surfaces for dynamic histomorphometric analyses, the mice were injected intraperitoneally with calcein $(20 \mathrm{mg} / \mathrm{kg})$ and then demeclocycline $(40 \mathrm{mg} / \mathrm{kg})$ at 48 and 24 hours prior to euthanasia, respectively. The 24-hour labeling interval was selected based on the expected high rate of bone formation and turnover in the C1HR mice, ${ }^{(30)}$ and although the interval was too short to give consistent dual bands of labels in the wild-type mice, it did yield adequate dual fluorescent labels in the C1HR mice.

\section{Blood biochemistry}

Blood was collected from the mice prior to euthanasia. Plasma total calcium was determined using a Calcium LiquiColor Test kit (Stanbio Laboratory, Boerne, TX). Plasma inorganic phosphate was determined using a Phosphate Colorimetric Assay Kit (BioVision, Inc, San Francisco, CA, USA). Plasma C-terminal telopeptides of type I collagen (CTX1) was determined using the RatLaps EIA kit (Immunodiagnostic Systems Inc., Fountain Hills, AZ, USA).

\section{Histology}

Tibias were harvested, fixed with $10 \%$ formalin overnight and then washed in PBS and transferred to $70 \% \mathrm{EtOH}$. The fixed nondecalcified tibias were dehydrated (graded ethanol) and subsequently infiltrated and embedded in methylmethacrylate. Longitudinal sections $(5 \mu \mathrm{m})$ were cut and stained with Goldner's Trichrome for measurements of cellular parameters, and by the method of von Kossa ${ }^{(33)}$ to evaluate bone mineralization. Dynamic bone parameters were evaluated on unstained sections by measuring the extent and the distance between double labels using the Osteomeasure analyzing system (Osteometrics Inc., Decatur, GA, USA). The structural, dynamic, and cellular parameters were evaluated using standardized guidelines. ${ }^{(34)}$

\section{Micro-computed tomography}

Microcomputed tomography $(\mu \mathrm{CT})$ analysis was performed on dissected bones using a desktop microtomographic imaging system ( $\mu \mathrm{CT}$ 40; Scanco Medical AG, Brüttisellen, Switzerland). Samples were scanned with a $10-\mu \mathrm{m}$ isotropic voxel size, $70-\mathrm{kV}$ peak potential $(\mathrm{kVp}), 114-\mu \mathrm{A} X$-ray tube intensity, and 300-ms integration time. Intramedullary bone and total volume were assessed in the distal femoral metaphysis in a region beginning at the peak of the growth plate and extending proximally for $1.0 \mathrm{~mm}$ (100 transverse slices) as well as in a region of the proximal tibial metaphysis beginning $0.1 \mathrm{~mm}$ inferior to the growth plate and extending distally for $1.0 \mathrm{~mm}$ (100 transverse slices). At the femoral mid-shaft, analysis was performed on a $0.5-\mathrm{mm}$ long region (50 transverse slices) to measure medullary total area (Ma.TA) and medullary bone area (Ma.BA); the Ma.BA was normalized to the Ma.TA at each slice, and the mean value reported as the medullary bone area fraction (Ma.BA/TA).

\section{Quantitative real-time (RT) PCR of bone cell mRNAs}

Total RNA was prepared from femoral diaphyses with epiphyses and perichondrium removed and the marrow left unflushed. The bones were homogenized in TRIzol using a Dremel Tissue Tearor homogenizer (Dremel, Racine, WI, USA), and total RNA was extracted by phase separation with chloroform followed by precipitation in isopropanol and then purified using an RNAeasy Mini kit (Qiagen, Hilden, Germany). The total RNA was then reversed-transcribed and the cDNA was processed using a
$\operatorname{TaqMan}^{\circledR}$ quantitative RT-PCR system (TaqMan ${ }^{\circledR}$ Gene Expression Assays; Thermo Fisher Scientific, Waltham, MA, USA). For each gene, the measured mRNA level in each sample was normalized to the level of $18 \mathrm{~S}$ rRNA in that sample and then expressed relative to the normalized level of that mRNA observed in the samples from vehicle-treated wild-type mice. The TaqMan ${ }^{\circledR}$ probes used are shown in Supporting Fig. S5.

\section{Data analysis}

Data were processed using Microsoft Excel-2016 (Redmond, WA, USA) and GraphPad Prism 8.2 (La Jolla, CA, USA) software packages. Statistical analyses were performed (Prism) using a oneway ANOVA with Tukey's post hoc comparisons of means when ANOVA was significant. Values of $p<.05$ indicate significance.

\section{Results}

\section{Inverse agonist properties in vitro}

The primary structure of $\left[\operatorname{Leu}^{11}, \mathrm{dTrp}^{12}, \operatorname{Trp}^{23}, \mathrm{Tyr}^{36}\right]-\mathrm{PTHrP}(7-36)$ $\mathrm{NH}_{2}{ }^{(28,29)}$ and its mode of action on the PTHR1-H223R mutant of JMC are depicted in Fig. $1 A$. In functional studies in vitro, [Leu ${ }^{11}, \mathrm{dTrp}^{12}{ }^{12} \mathrm{Trp}^{23}, \mathrm{Tyr}^{36}$ ]-PTHrP(7-36) $\mathrm{NH}_{2}$ was more effective as an inverse agonist than the PTH-based analog, $\left[\mathrm{Nle}^{8,18}, \mathrm{dTrp}^{12}\right.$, $\mathrm{Tyr}^{34}$ ]-bPTH(7-34) $\mathrm{NH}_{2}{ }^{(24,25)}$ because it more effectively reduced basal CAMP signaling in HEK293 cells stably transfected to express PTHR1-H223R and the GloSensor CAMP reporter (Fig. $1 B, C$ ). Based on these and prior cell-based studies ${ }^{(28,29)}$ $\left[\right.$ Leu $^{11}, \mathrm{dTrp}^{12}, \operatorname{Trp}^{23}, \mathrm{Tyr}^{36}$ ]-PTHrP(7-36) $\mathrm{NH}_{2}$ was selected for the studies in vivo described in the following sections.

\section{Properties of Col1-PTHR-H223R mice and peptide dose selection}

Col1-H223R transgenic mice (referred to as C1HR mice herein) express the PTHR1-H223R variant under the control of the collagen1a1 promoter, which is active predominantly in osteoblasts. $^{(30)}$ Compared to wild-type mice, C1HR mice exhibit a pronounced accumulation of trabecular bone in the marrow compartments of the long bones, a thinning of the bone cortices, an accumulation of fibrotic stromal cells in the marrow spaces between bone trabeculae, and high rates of bone turnover. $^{(30,31,35)}$ In a pilot study, we found that once-daily injection of $\quad\left[\mathrm{Leu}^{11}{ }^{11} \mathrm{dTrp}{ }^{12}, \mathrm{Trp}^{23}, \mathrm{Tyr}^{36}\right]-\mathrm{PTHrP}(7-36) \mathrm{NH}_{2}$, henceforth referred to as inverse agonist or IA, into the $\mathrm{C} 1 \mathrm{HR}$ mice for 2 weeks at a daily dose of $500 \mathrm{nmol} / \mathrm{kg}$ did not result in any noticeable change in the bone phenotype, as assessed histologically at the proximal tibias. For the current experiment, we sought to increase ligand exposure and thus injected the mice BID with the IA analog at a dose of $500 \mathrm{nmol} / \mathrm{kg} / \mathrm{injection}$. The injections were started on postnatal day 7 and continued every 12 hours for 17 days. As controls, C1HR littermate mice were injected with vehicle, and wild-type littermates were injected with either vehicle or inverse agonist. The C1HR mice were small, with body weights that were about $60 \%$ less than that of their wild-type littermates, as reported. ${ }^{(30)}$ For either the wild-type or C1HR mice, no change in mean body weight occurred with inverse agonist treatment, as compared to with vehicle treatment (Supporting Fig. S1A), and the overall health appearance of the mice did not change over the 17-day treatment period. Twelve hours after the last injection, the mice were euthanized and bones as well as blood and urine samples were collected for analysis. 

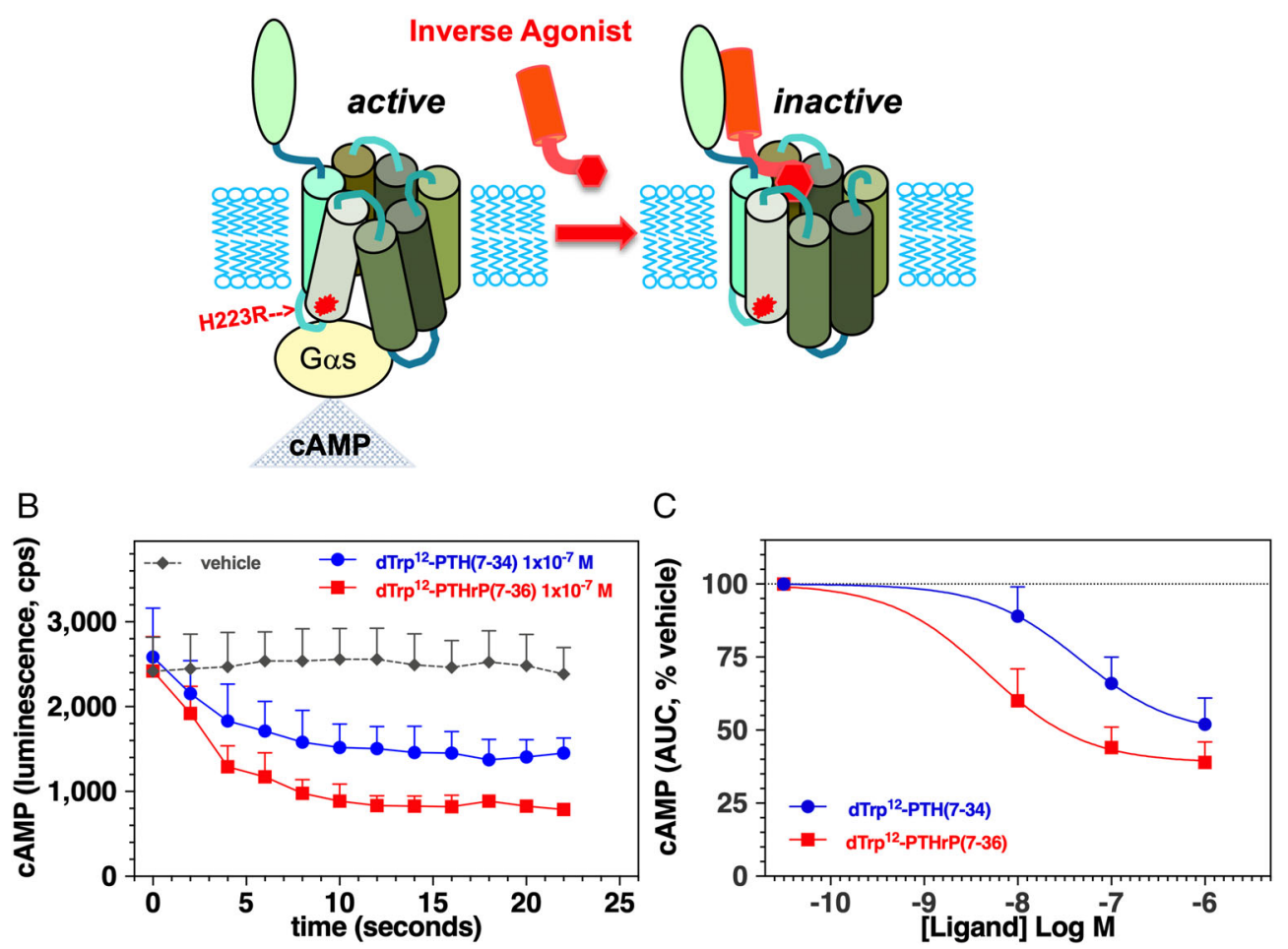

Fig. 1. Properties of the inverse agonist ligand. (A) The primary structure of the inverse agonist analog used for in vivo studies, $\left[\operatorname{Leu}^{11}, \mathrm{dTrp}{ }^{12}, \operatorname{Trp}^{23}, \operatorname{Tyr}^{36}\right]-$ PTHrP(7-36) $\mathrm{NH}_{2}{ }^{(28)}$ with residues not native to human PTHrP shown in blue circles, and a model of inverse agonism. The H223R mutation of JMC is located at the base of TM helix 2 and induces an active-state receptor conformation that mediates ligand-independent G $\alpha \mathrm{S}$ coupling and cAMP signaling; binding of the inverse agonist reverts the receptor to an inactive conformation and decreases basal signaling. $(B)$ Inverse agonist responses in $\mathrm{HEK} 293$ cells stably expressing PTHR1-H223R and the GloSensor cAMP reporter (GHR-10 cells); the cells were treated with $\left[\right.$ Leu $\left.^{11}, \mathrm{dTrp}^{12}{ }^{12} \operatorname{Trp}^{23}, \mathrm{Tyr}^{36}\right]-\mathrm{PTHrP}(7-36) \mathrm{NH}{ }_{2}\left\{\mathrm{dTrp}{ }^{12}\right.$ PTHrP (7-36)\} or the PTH-based antagonist/inverse agonist, $\left[\mathrm{dTrp}^{12}, \mathrm{Nle}^{8,18}, \mathrm{Tyr}^{34}\right]-\mathrm{bPTH}(7-34) \mathrm{NH}_{2}{ }^{(25)}\left\{\mathrm{dTrp}{ }^{12}-\mathrm{PTH}(7-34)\right\}$, each at 100nM, or with vehicle, and CAMP-dependent GloSensor luminescence was recorded at 2-min intervals for $22 \mathrm{~min}$. (C) Dose-response curves generated from the areas-under-thecurve of time-course data obtained as in $B$ at varying concentrations of ligand. Data are means $\pm S D$ of three experiments, each in duplicate.

Inverse agonist treatment reduces bone mass and increases bone length in C1HR mice

$\mu \mathrm{CT}$ was used to assess the effects of inverse agonist treatment on bone mineral density and bone structure in the C1HR mice. $\mu \mathrm{CT}$ scans of the femurs and tibias isolated from the vehicle-treated $\mathrm{C} 1 \mathrm{HR}$ mice revealed the expected marked increases in trabecular bone in the metaphyseal regions of the distal femur and proximal tibia, as well as in the medullary region of the femur mid-shaft, as compared to the corresponding regions of the bones isolated from vehicle-treated wild-type mice (Fig. 2A,B, Supporting Figs. S1B and S2). Quantification of bone volume fraction (BV/TV, \%) and bone mineral density ( $\mathrm{mg}$ hydroxyapatite/ $\mathrm{cm}^{3}$ ) in the metaphyseal regions of the distal femurs and proximal tibias, and of cross-sectional bone area at the femoral mid-shaft confirmed this increase in bone in the vehicle-treated C1HR mice relative to the vehicle-treated wild-type mice (Fig. $2 C$ ). Significantly less bone was measured in these compartments of the femurs and tibias obtained from C1HR mice treated with inverse agonist, as compared to the bones from vehicle-treated $\mathrm{C} 1 \mathrm{HR}$ mice (Fig. 2A-C, Supporting Figs. S1B and S2). No change in these structural parameters was observed in the bones obtained from wild-type mice treated with inverse agonist, as compared to those obtained from wild-type mice treated with vehicle.

Inverse agonist treatment reduces osteoblast number, bone marrow fibrosis, and bone formation rates in C1HR mice

We further explored the effects of the inverse agonist on bone properties by examining histological sections of the proximal tibias obtained from the mice. Consistent with the $\mu C T$ imaging, staining of the tibia sections with von Kossa dye revealed the expected increase in mineralized trabecular bone in the tibias of the vehicle-treated C1HR mice, as compared to those of the vehicle-treated wild-type mice, and this trabecular bone mass was reduced in the $\mathrm{C} 1 \mathrm{HR}$ mice by inverse agonist treatment (Fig. 3A). Higher magnification views of sections stained with the Goldner's Trichrome reagent revealed the expected accumulation of fibrotic, stromal-like cells in the intertrabecular spaces in the tibias from the vehicle-treated C1HR mice, whereas these spaces in bones from wild-type mice were populated by smaller hematopoietic-type cells ${ }^{(30,31,35,36)}$ (Fig. 3B). 
A

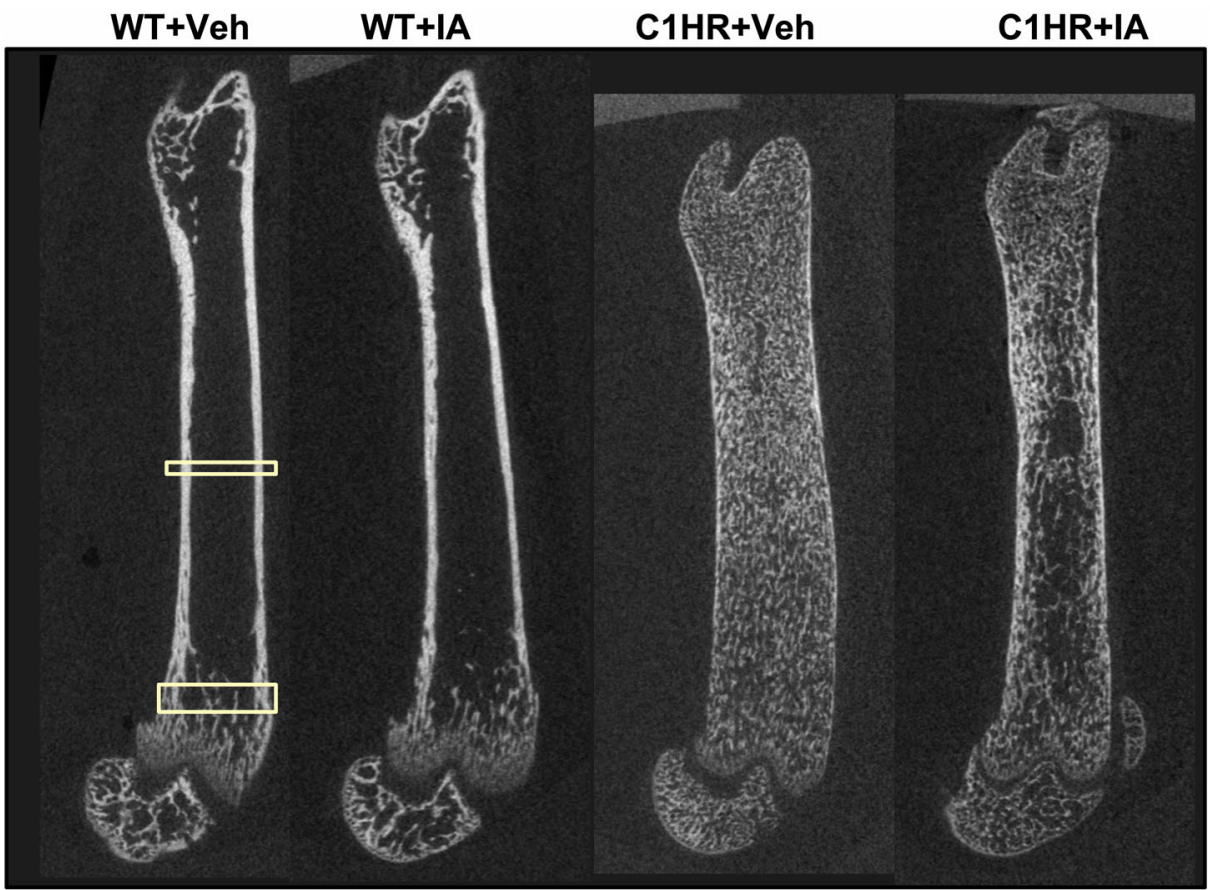

$\mathrm{B}$



C Distal femur trabecular bone volume

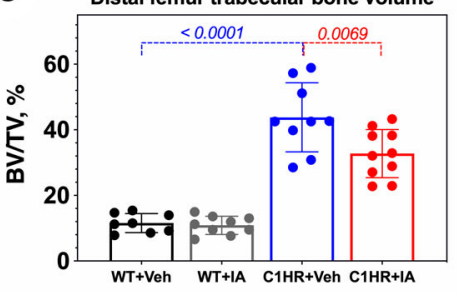

Distal femur trabecular bone mineral density
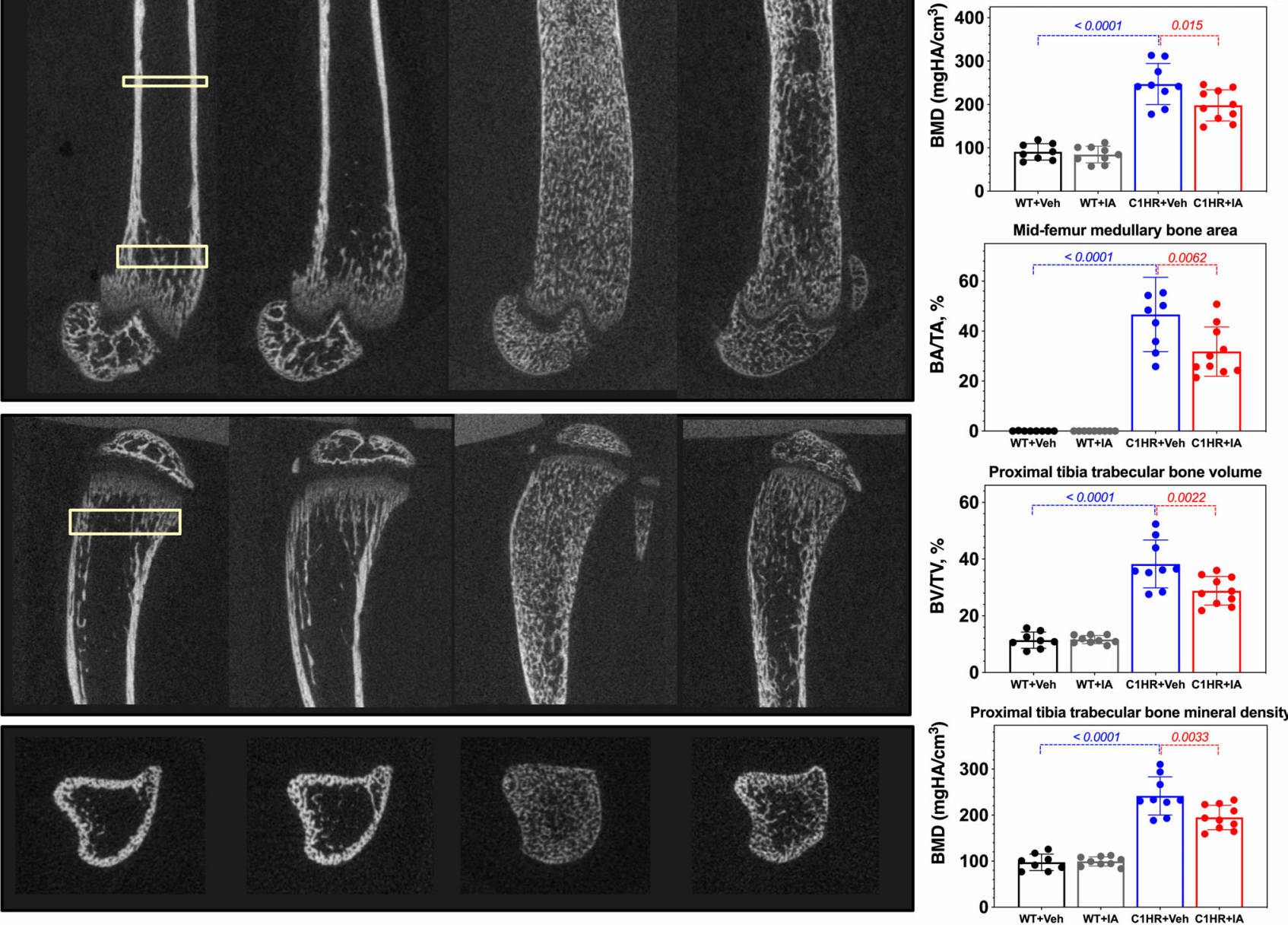

Fig. 2. $\mu C T$ analysis of the effects of inverse agonist treatment on bone density in WT and C1HR mice. Femurs and tibias isolated from WT and C1HR mice after 17 days of treatment with inverse agonist, IA, or Veh were analyzed by $\mu \mathrm{Ct}$. (A) Representative sagittal views of the whole femur. (B) Representative sagittal views and corresponding transverse views of the proximal tibia. (C) Quantification of trabecular BV/TV (\%) and BMD (mg hydroxyapatite/cm $\left.{ }^{3}\right)$ at the distal femur and proximal tibia, and of cross-sectional medullary BA/TA (\%) at the femur mid-shaft. Measurements were made between the cortices in the regions of interest shown by the boxes in the vehicle-treated WT images in $A$ and $B$. Data are means \pm SD; $p$ values (Tukey's multiple comparison test after ANOVA) are shown for paired groups marked by brackets ( $n=8-10$ per group). $\mu \mathrm{CT}=$ micro-computed tomography; $\mathrm{C} 1 \mathrm{HR}=\mathrm{Col} 1-\mathrm{PTHR} 1-\mathrm{H} 223 \mathrm{R} ; \mathrm{WT}$ = wild-type; Veh = vehicle; IA = $\left[\right.$ Leu $\left.^{11}, \mathrm{dTrp}^{12}, \mathrm{Trp}^{23}, \mathrm{Tyr}^{36}\right]-\mathrm{PTHrP}(7-36) \mathrm{NH}_{2} ; \mathrm{BV} / \mathrm{TV}=$ bone volume relative to tissue volume; $\mathrm{BMD}=$ bone mineral density; $\mathrm{BA} / \mathrm{TA}=$ bone area relative to total area.

Treatment with the inverse agonist reduced the abundance of these fibrotic cells in the tibiae of the C1HR mice, as compared to the amounts of these cells seen in the tibias from the C1HR mice injected with vehicle, and there was concomitantly an apparent increase in the abundance of smaller hematopoietic-type cells (Fig. 3B). Quantitative histomorphometric analyses confirmed these observations, as inverse agonist treatment, relative to vehicle treatment in the C1HR mice significantly reduced the measured bone mass, the number of bone trabeculae, as well as the amount of marrow cell fibrosis (Fig. 3C, Supporting Table S1). Inverse agonist treatment in C1HR mice also reduced the number of osteoblasts per unit length of bone perimeter, whereas it increased the number of osteoclasts; the latter effect could be explained by a reduction in the total bone area in the C1HR mice with a corresponding smaller change in the total number of osteoclasts in the measured area (Fig. 3C, Supporting Table S1). 
A
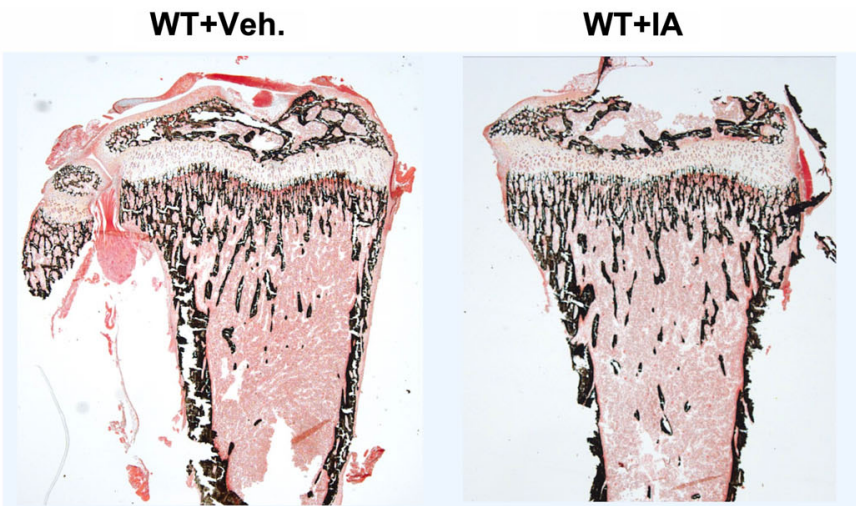

C1HR+Veh.

C1HR+IA
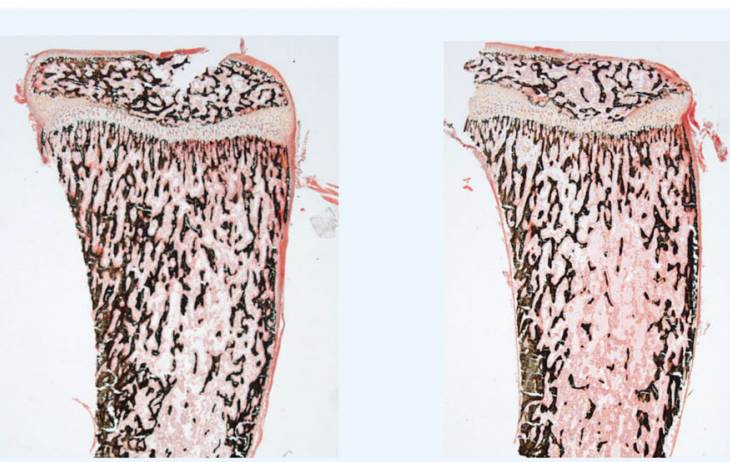

B

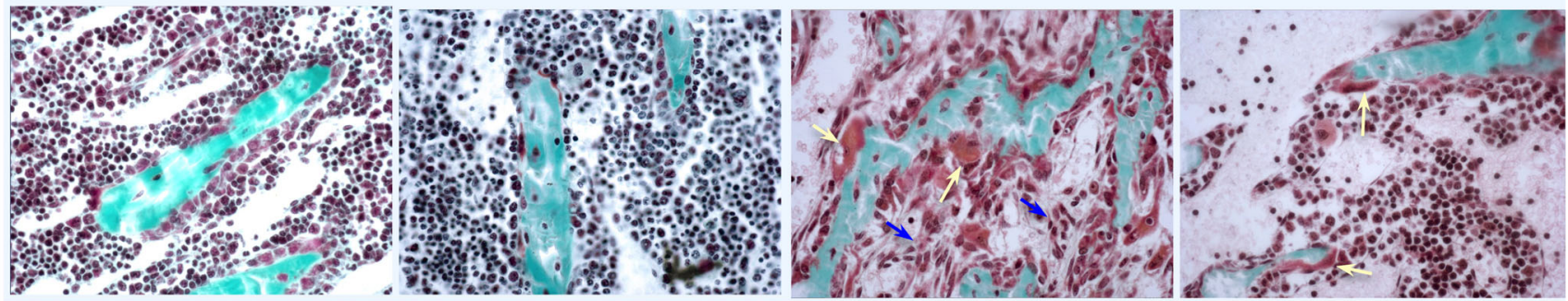

C
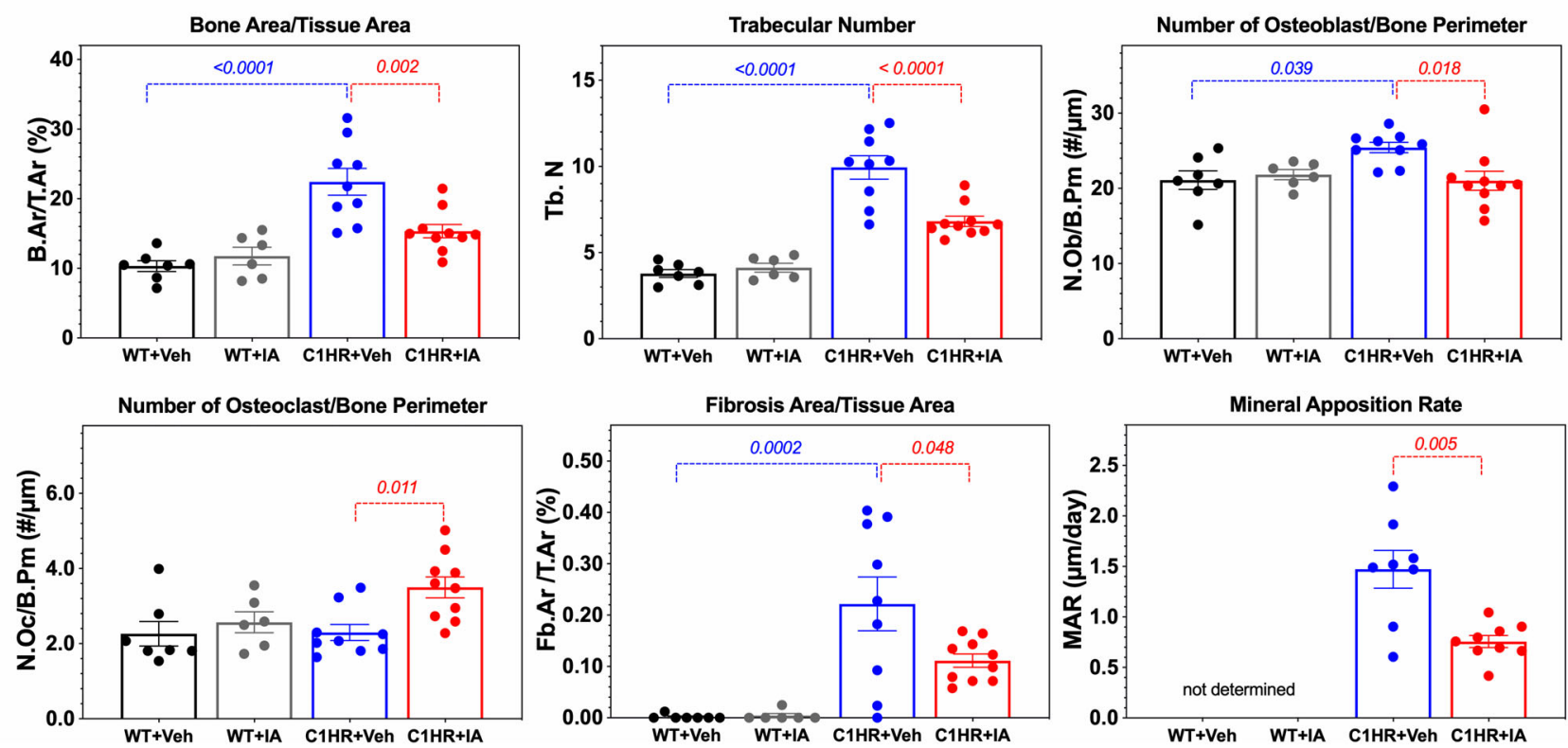

Fig. 3. Histological analysis of the effects of inverse agonist treatment on bone in WT and C1HR mice. Tibias isolated from WT and C1HR mice after 17 days of treatment with IA or Veh were analyzed histologically in the proximal region. (A) Representative sagittal views of sections stained with von Kossa dye to show mineralized bone tissue (magnification $\times 40)$. (B) Higher magnification $(\times 400)$ views of sections stained with Goldner's trichrome dye to show bone trabeculae (green) and surrounding cells and tissue. Blue arrows in the C1HR + Veh image point to areas of stromal cell fibrosis; yellow arrows point to osteoclasts. (C) Quantification of histomorphometric parameters in a region just below the center of the growth plate in the proximal tibia. Mineral apposition rate was not determined in bones of WT mice due to inadequate separation of double labels. Data are means \pm SD; $p$ values (Tukey's multiple comparison test after ANOVA) are shown for paired groups marked by brackets ( $n=8-10$ per group). Additional histomorphometric data are shown in Supporting Fig. S3 and Supporting Table S1. WT = wild-type; C1HR = Col1-PTHR1-H223R; IA = inverse agonist; Veh = vehicle.

The differences given in the previous paragraph in bone structural parameters observed in the $\mathrm{C} 1 \mathrm{HR}$ mice treated with or without inverse agonist likely reflect, at least in part, effects on rates of bone formation. To assess rates of bone mineralization and formation, the mice were sequentially injected with the fluorescent bone-labeling dyes, calcein and demeclocycline, at two days and one day, respectively, before the last injection (day
17). The 24-hour interval between dye injections was selected based on the higher bone formation rate predicted for the C1HR mice from previous studies. ${ }^{(30,31)}$ This interval was too short to provide consistent double labels in the bones of wildtype mice, which precluded reliable rate measurements in the bones of these animals. In the bones of the C1HR mice, adequate double labels were obtained, and the distances measured 
between the two labels clearly indicated that inverse agonist treatment reduced the rates of bone mineral apposition and bone formation in C1HR mice (Fig. 3C, Supporting Fig. S3B, Supporting Table S1).

\section{Inverse agonist treatment reduces markers of bone turnover in $\mathrm{C} 1 \mathrm{HR}$ mice}

Serum levels of carboxy-terminal crosslinked telopeptide of type I collagen (CTX1) were significantly elevated in the vehicletreated $\mathrm{C} 1 \mathrm{HR}$ mice, as compared to the levels in the vehicletreated wild-type mice, and these levels in C1HR mice were reduced by inverse agonist treatment (Fig. 4A). Serum concentrations of total calcium (Ca) were not different between the four groups, whereas serum inorganic phosphorus ( $\mathrm{Pi}$ ) was unchanged between groups of wild-type mice and the vehicletreated C1HR mice but was significantly reduced in C1HR mice treated with the inverse agonist, as compared to $\mathrm{C} 1 \mathrm{HR}$ mice treated with vehicle (Fig. 4B,C). Urine levels of both $\mathrm{Ca}$ and $\mathrm{Pi}$ were significantly elevated in vehicle-treated C1HR mice, and were reduced in the $\mathrm{C} 1 \mathrm{HR}$ mice by inverse agonist treatment, although the effect was significant only for urine Ca (Fig. 4D,E). The elevations in urine $\mathrm{Ca}$ and $\mathrm{Pi}$, and plasma CTX1 observed in the vehicle-treated $\mathrm{C} 1 \mathrm{HR}$ mice, as compared to the levels in wild-type mice, are consistent with an increase in the rate of osteoclast-mediated bone resorption, as induced indirectly by the constitutive signaling activity of the mutant PTHR1-H223R in bone osteoblasts, whereas the reductions in these markers with inverse agonist treatment are consistent with a suppression of PTHR1-H223R signaling activity in the osteoblasts of the transgenic mice and an indirect suppression of osteoclast-mediated bone turnover.
The levels of mRNAs encoding several osteoblast-produced proteins that are regulated by PTHR1 signaling, including collagen-1a1, the receptor activator of nuclear factor-kappaB ligand (RANKL), which stimulates osteoclast differentiation and activity, and osteoprotegerin (OPG), which inhibits RANKL by acting as a decoy receptor, ${ }^{(37)}$ as well as the osteoclastic gene product, tartrate-resistant acid phosphatase 5b (TRAP5b), were elevated in femurs isolated from vehicle-treated C1HR mice, as compared to femurs isolated from vehicle-treated wild-type mice (Supporting Fig. S4). Inverse agonist treatment had only a minor if any effect on the levels of these mRNAs in C1HR mice, although collagen-1a1 mRNA levels were reduced significantly $(p=.048)$.

\section{DISCUSSION}

Because JMC is an ultra-rare disease, with only about 30 cases identified since its first description in $1934,{ }^{(1,7)}$ it has garnered little if any interest from the pharmaceutical industry in terms of therapeutic development. There is thus no effective drug therapy available for the disease, despite a clear medical need ${ }^{(6)}$ and precise knowledge of the molecular target. ${ }^{(27,38,39)}$ Those considerations provided the key impetus for the current study, which is the first time that an inverse agonist ligand for a constitutively active mutant PTHR1 has been tested in vivo. The overall results provide proof-of-concept support for the hypothesis that such an inverse agonist ligand can be effective at suppressing the constitutive activity of a JMC PTHR1 variant in vivo. We thus found that administration of $\left[\mathrm{Leu}^{11}, \mathrm{dTrp}^{12}, \mathrm{Trp}^{23}, \mathrm{Tyr}^{36}\right]$-PTHrP (7-36) $\mathrm{NH}_{2}$ to $\mathrm{C} 1 \mathrm{HR}$ mice expressing the PTHR1-H223R mutant allele in osteoblasts can prevent and/or correct at least some of
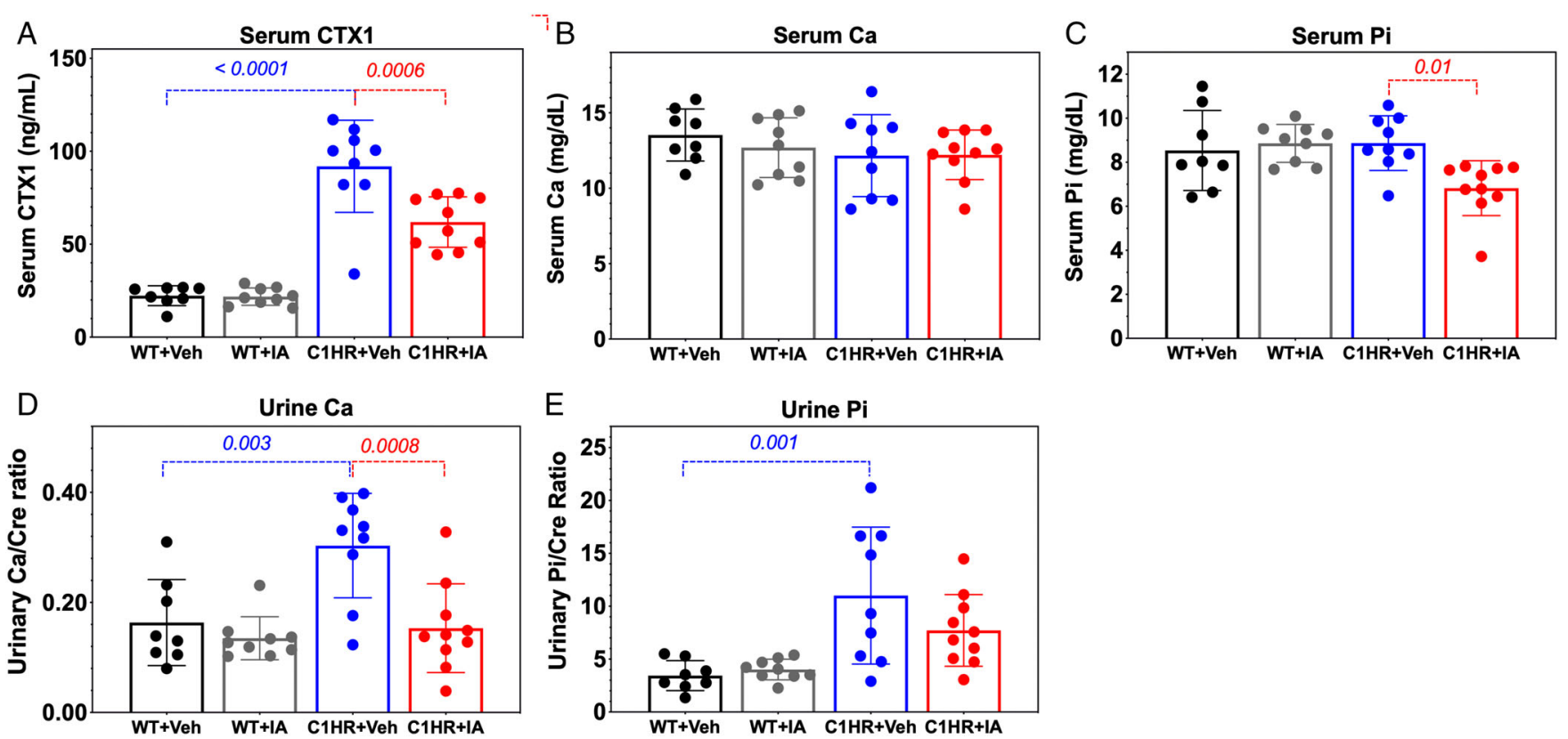

Fig. 4. Effects of inverse agonist treatment on markers of bone and mineral metabolism in blood and urine. Blood and urine samples collected from WT and $\mathrm{C} 1 \mathrm{HR}$ mice after 17 days of treatment with IA or Veh were analyzed for CTX1 $(A)$, total calcium $(B, D)$, and Pi (urine values are normalized to creatinine) $(C, E)$. Data are means $\pm \mathrm{SD} ; p$ values (Tukey's multiple comparison test after ANOVA) are shown for paired groups marked by brackets $(n=8-10$ per group). WT = wild-type; $\mathrm{C} 1 \mathrm{HR}=\mathrm{Col1}-\mathrm{PTHR} 1-\mathrm{H} 223 \mathrm{R} ; \mathrm{IA}=$ inverse agonist; $\mathrm{Veh}=$ vehicle; $\mathrm{Pi}=$ inorganic phosphate. 
the skeletal and mineral ion abnormalities that otherwise occur in these JMC model mice.

We selected the $\left[\mathrm{Leu}^{11}, \mathrm{dTrp}{ }^{12}, \operatorname{Trp}^{23}, \operatorname{Tyr}^{36}\right]-\mathrm{PTH} \mathrm{TP}(7-36) \mathrm{NH}_{2}$ analog for use in this study because of its proven effectiveness in suppressing the basal CAMP signaling activity of the PTHR1-H223R mutant in transfected cells. ${ }^{(28,29)}$ The C1HR transgenic mice were used as a model of JMC because they express the PTHR1-H223R mutant allele, which is the most common JMC disease variant, ${ }^{(7)}$ and they exhibit a robust, wellcharacterized phenotype in skeletal tissue, which is the main site affected in patients. After only 17 days of treatment the inverse agonist produced significant reductions in the excess trabecular bone mass that otherwise accumulates in the long bones of the $\mathrm{C} 1 \mathrm{HR}$ mice. It also quantitatively reduced the rate of new bone formation, the levels of bone resorption markers in the blood or urine, and the abundance of fibrotic stromal cells that otherwise populate the marrow compartments of the long bones of the C1HR mice. ${ }^{(35,36)}$

A surprising finding was that although inverse agonist treatment in the C1HR mice led to a significant reduction in serum levels of CTX1, it increased the number and/or size of osteoclasts lining the bone perimeters (Fig. 4A, Supporting Table S1). Although the underlying mechanisms are not clear, it is possible that the bone-resorbing activity of the osteoclasts did not increase proportionally with an increase in the size and/or number of these cells. An increase in osteoclast size and/or number with a concomitant decrease in serum CTX1 was observed previously by Ko and colleagues ${ }^{(40)}$ in young wild-type mice in response to 8 weeks of alendronate treatment. Although these findings appear similar to ours, the upstream mechanisms likely differ, because the effect involved treatment with a bisphosphonate, whereas our current study involves effects on PTHR1 signaling.

We detected no significant change in any bone parameter in wild-type mice treated with the inverse agonist. The absence of a skeletal effect in the wild-type mice suggests that the inverse agonist acts with at least some degree of selectivity on the PTHR1-H223R variant, relative to on the wild-type PTHR1, and thus can have efficacy toward that variant without causing major alterations to the normal physiology regulated by the wild-type PTHR1 and its two endogenous ligands, PTH and PTHrP, acting in the principal target tissues of bone and kidney. Although a formal toxicological analysis was not performed, there was no sign of systemic toxicity associated with ligand treatment in either the wild-type or C1HR mice. In support of this, IA treatment in either strain of mice resulted in no change in body weight, which provides at least an initial assessment of systemic drug toxicity $^{(41)}$ (Supporting Fig. S1A), nor a change in serum calcium (Fig. 4B).

The lengths of the tibias and femurs in the C1HR mice were $\sim 15 \%$ shorter than those in wild-type mice, consistent with prior studies, ${ }^{(31,42)}$ and the mean lengths of the bones in the $\mathrm{C} 1 \mathrm{HR}$ mice tended to increase modestly (3\% to $5 \%$ ) with IA treatment, although the effects were not significant (Supporting Table S2). Potential effects on bone length are of interest because impaired limb development and reduced overall height are prominent clinical features of JMC. ${ }^{(6)}$ An inverse agonist could conceivably induce changes in bone length in C1HR mice via actions in the growth plates, because expression of the PTHR1-H223R transgene is detected at low levels in growth plate chondrocytes of the $\mathrm{C} 1 \mathrm{HR}$ mice, $^{(30)}$ and PTHR1 signaling is well known to play a major role in growth plate chondrocyte differentiation and hence bone growth. ${ }^{(39,43-45)}$ We administered the inverse agonist starting at 7 days of age, and so the analog was present in the mice during a period of active bone growth. Elucidating how processes of growth plate maturation and bone growth might be altered by constitutive PTHR1 signaling and potentially modulated with an inverse agonist ligand are important research objectives, given the impact that such altered signaling has on skeletal development in children with JMC. ${ }^{(6,7)}$

The recent high-resolution structures of the PTHR1 in partially active $^{(12)}$ and active-state ${ }^{(13)}$ conformations, together with the structures obtained for several other family B GPCRs ${ }^{(11,20,46)}$ help shed light on the mechanisms by which the PTHR1 and these peptide hormone receptors as a class function. Particularly noteworthy is the finding that all known JMC mutations map to three residue positions in the PTHR1: His223, Thr410, and lle458, which are each located at the cytosolic base of a TMD helix and at a position that strongly suggests a critical role in receptor activation. His223 in TM2 and Thr410 in TM6 are thus seen to be directly involved in a network of polar residues that acts as a switch to control the outward movements of the TMD helices that occur during activation and which lead to the formation of a cavity on the cytosolic face of the receptor that is used for $G$ protein coupling. ${ }^{(11,20,46)}$ Ile458 in TM7 is adjacent to Tyr459, which also participates in the same polar network. A fourth key residue in this polar network of the PTHR1 is Glu302 in TM3, which so far has not been associated with JMC. Overall, the disease phenotype of JMC patients confirms the functional significance of this polar network. Although this polar network is highly conserved in class B GPCRs, we are not aware of another disorder that is caused by an activating mutation in any of these other GPCRs, even though mutations introduced at these sites in several of them have been shown to result in constitutive activity when tested in transfected cells. ${ }^{(20,47)}$ Whether the apparent absence of a disease association for these other receptors is due to poor expression of the constitutively active mutant allele in the respective target tissue, or by some other overriding factor is unknown.

The current structural data predict that the PTHR1 mutations of JMC shift the receptor to an active-state conformation by perturbing key molecular interactions that occur within the polar network at the base of the TMD bundle. The mechanism by which the binding of the inverse agonist ligand to the receptor's extracellularly exposed orthosteric pocket promotes the inactive receptor conformation is less clear. The $\mathrm{dTrp}^{12}$ modification of the ligand, which replaces the L-glycine that is conserved at this position in native PTH and PTHrP agonist ligands, is likely to play a key role, because it is required for the inverse agonist effect. ${ }^{(27)}$ Several small-molecule antagonist ligands have been identified for the PTHR1, but none so far has been reported to function as an inverse agonist. ${ }^{(29,48,49)}$

The rarity of JMC is likely to be at least partly explained by a limited number of sites in the PTHR1 that can result in functional constitutive activity when mutated; ie, those impacting the conserved polar residue network comprised of His223, Glu302, Thr410, and Tyr458. In contrast to the activating mutations of JMC, heterozygous loss-of-function mutations have been identified at a number of dispersed sites in the PTHR1 in patients with defects in tooth eruption. ${ }^{(50)}$ In the very rare homozygous state, such loss-of-function PTHR1 mutations lead to the perinatal lethal condition of Blomstrand's chondrodysplasia, ${ }^{(51)}$ which is characterized by a hypermineralized skeleton, in contrast to the low bone mineral density seen in patients with JMC. ${ }^{(6)}$

In summary, treatment of mice with an inverse agonist ligand improved at least some of the skeletal and mineral ion defects 
caused by transgenic expression in osteoblasts of a constitutively active PTHR-H223R allele of JMC. This study is the first demonstration that an inverse agonist for the PTHR1 can be effective in vivo, and thus provides proof-of-concept support for the notion that such a ligand could potentially be developed as a therapy for JMC. Although full phenotypic rescue was not achieved in the current, short-term studies, this was not an essential goal, given that the transgenic mice utilized here, as well as other available JMC transgenic mice, ${ }^{(52,53)}$ are not precise models of the disease, because the mutant allele in the mice is expressed in a restricted tissue or cell type, eg, bone osteoblasts, whereas in patients it is expressed in all endogenous PTHR1 target sites, including bone, kidneys, and the growth-plates. The current findings nevertheless show that inverse agonist efficacy in vivo is possible for the mutant PTH receptors of JMC, and they also suggest that further studies aimed at improving the receptor-binding properties of such ligands as well as their pharmacokinetic properties should be important goals of future research.

\section{Disclosures}

Research grant support was provided by Chugai Pharmaceutical Company, Japan (to TJG and JTP) and Sanofi Genzyme Corp. Cambridge, MA (TJG and HJ). HN is an employee of Chugai Pharmaceutical Company and contributed to the work while a research appointee at MGH and supervised by TJG and HJ.

\section{Acknowledgments}

This work was supported by research grants from the $\mathrm{NIH}$ (DK12444791 to HJ and TJG; DK11794 to HJ, JTP, and TJG; AR066261 to MA, JSD, DJB, MB, MD, and TJG); Chugai pharmaceutical Company Jp (to HN, HJ, JTP, and TJG); and from SanofiGenzyme Corp. Cambridge, MA, USA (to HJ and TJG). We thank Drs. Tomoyuki Watanabe and Akira Maeda, for pilot mouse experiments, Dr. Hiroshi Saito for assistance with the injections, and Drs. Shigeki Nishimori and Drs. Henry M. Kronenberg for valuable comments and guidance.

\section{References}

1. Jansen M. [About atypical chondrodystrophy (achondroplasia) and an as yet unspecified congenital growth disorder of the bony system: metaphyseal dysostosis] Über atypische chondrodystrophie (achondroplasie) und über eine noch nicht beschriebene angeborene wachstumsstörung des knochensystems: metaphysäre dysostosis. Zeitschrift Orthopädie Chirurgie 1934;61:253-86. German.

2. Schipani $E$, Kruse $K$, Jüppner H. A constitutively active mutant PTHPTHrP receptor in Jansen-type metaphyseal chondrodysplasia. Science. 1995;268:98-100.

3. Rao D, Frame B, Reynolds W, Parfitt A. Hypercalcemia in metaphyseal chondrodysplasia of Jansen (MCD): an enigma. In Norman AW, Schaefer K, von Herrath D, Grigoleit HG, Coburn JW, HF DL, Mawer EB, Suda T, eds. Vitamin D, basic research and its clinical application. Berlin: Walter de Gruyter; 1979 pp 1173-6.

4. Kruse K, Schutz C. Calcium metabolism in the Jansen type of metaphyseal dysplasia. Eur J Pediatr. 1993;152:912-5.

5. Parfitt AM, Schipani E, Rao DS, Kupin W, Han ZH, Juppner H. Hypercalcemia due to constitutive activity of the parathyroid hormone (PTH)/PTH-related peptide receptor: comparison with primary hyperparathyroidism. J Clin Endocrinol Metab. 1996;81:3584-8.

6. Nampoothiri S, Fernandez-Rebollo E, Yesodharan D, et al. Jansen metaphyseal chondrodysplasia due to heterozygous H223R-PTH1R mutations with or without overt hypercalcemia. J Clin Endocrinol Metab. 2016;101:4283-9.

7. Saito $H$, Noda $H$, Gatault $P$, et al. Progression of mineral ion abnormalities in patients with Jansen metaphyseal mhondrodysplasia. J Clin Endocrinol Metab. 2018;103:2660-9.

8. Lanske B, Karaplis A, Lee K, et al. PTH/PTHrP receptor in early development and indian hedgehog-regulated bone growth. Science. 1996; 273:663-6.

9. Parfitt AM. Bone and plasma calcium homeostasis. Bone. 1987;8 (Suppl 1):S1-8.

10. Cheloha RW, Gellman SH, Vilardaga JP, Gardella TJ. PTH receptor-1 signalling-mechanistic insights and therapeutic prospects. Nat Rev Endocrinol. 2015;11(12):712-24.

11. de Graaf C, Song G, Cao C, et al. Extending the structural view of class B GPCRs. Trends Biochem Sci. 2017;42:946-60.

12. Ehrenmann J, Schoppe J, Klenk C, et al. High-resolution crystal structure of parathyroid hormone 1 receptor in complex with a peptide agonist. Nat Struct Mol Biol. 2018;25:1086-92.

13. Zhao L-H, Ma S, Sutkeviciute I, et al. Structure and dynamics of the active human parathyroid hormone receptor-1. Science. 2019;364: 148-53.

14. Zhang Y, Sun B, Feng D, et al. Cryo-EM structure of the activated GLP1 receptor in complex with a G protein. Nature. 2017;546:248-53.

15. Liang $Y L$, Khoshouei $M$, Radjainia $M$, et al. Phase-plate cryo-EM structure of a class B GPCR-G-protein complex. Nature. 2017;546:1 18-23.

16. Zhang $H$, Qiao A, Yang $L$, et al. Structure of the glucagon receptor in complex with a glucagon analogue. Nature. 2018;553:106-10.

17. Thal DM, Vuckovic Z, Draper-Joyce CJ, et al. Recent advances in the determination of $\mathrm{G}$ protein-coupled receptor structures. Curr Opin Struct Biol. 2018;51:28-34.

18. Liang $Y L$, Khoshouei $M$, Deganutti $G$, et al. Cryo-EM structure of the active, Gs-protein complexed, human CGRP receptor. Nature. 2018; 561:492-7.

19. Schipani E, Jensen GS, Pincus J, Nissenson RA, Gardella TJ, Juppner $H$. Constitutive activation of the cyclic adenosine $3^{\prime}, 5^{\prime}$-monophosphate signaling pathway by parathyroid hormone (PTH)/PTH-related peptide receptors mutated at the two loci for Jansen's metaphyseal chondrodysplasia. Mol Endocrinol. 1997;11:851-8.

20. Yin Y, de Waal PW, He Y, et al. Rearrangement of a polar core provides a conserved mechanism for constitutive activation of class B G protein-coupled receptors. J Biol Chem. 2017;292:9865-81.

21. Costa T, Herz A. Antagonists with negative intrinsic activity at delta opioid receptors coupled to GTP-binding proteins. Proc Natl Acad Sci U S A. 1989;86:7321-5.

22. Chidiac $P$, Hebert TE, Valiquette M, Dennis M, Bouvier M. Inverse agonist activity of beta-adrenergic antagonists. Mol Pharmacol. 1994;45: 490-9.

23. Berg KA, Clarke WP. Making sense of pharmacology: inverse agonism and functional selectivity. Int J Neuropsychopharmacol. 2018;21: 962-77.

24. Rosen HN, Lim M, Garber J, et al. The effect of PTH antagonist BIM44002 on serum calcium and PTH levels in hypercalcemic hyperparathyroid patients. Calcif Tissue Int. 1997;61:455-9.

25. Goldman ME, McKee RL, Caulfield MP, et al. A new highly potent parathyroid hormone antagonist: [D-Trp12,Tyr34]bPTH-(7-34)NH2. Endocrinology. 1988;123:2597-9.

26. Carter $\mathrm{PH}$, Juppner $\mathrm{H}$, Gardella TJ. Studies of the $\mathrm{N}$-terminal region of a parathyroid hormone-related peptide (1-36) analog: receptor subtype-selective agonists, antagonists, and photochemical crosslinking agents. Endocrinology. 1999;140:4972-81.

27. Gardella TJ, Luck MD, Jensen GS, Schipani E, Potts JT Jr, Juppner H. Inverse agonism of amino-terminally truncated parathyroid hormone (PTH) and PTH-related peptide (PTHrP) analogs revealed with constitutively active mutant PTH/PTHrP receptors. Endocrinology. 1996;137:3936-41.

28. Carter PH, Petroni BD, Gensure RC, Schipani E, Potts JT Jr, Gardella TJ. Selective and nonselective inverse agonists for constitutively active type-1 parathyroid hormone receptors: evidence for altered receptor conformations. Endocrinology. 2001;142:1534-45. 
29. Carter PH, Dean T, Bhayana B, Khatri A, Rajur R, Gardella TJ. Actions of the small molecule ligands SW106 and AH-3960 on the type-1 parathyroid hormone receptor. Mol Endocrinol. 2015;29:307-21.

30. Calvi LM, Sims NA, Hunzelman JL, et al. Activated parathyroid hormone/parathyroid hormone-related protein receptor in osteoblastic cells differentially affects cortical and trabecular bone. J Clin Invest. 2001;107:277-86

31. Ohishi M, Chiusaroli R, Ominsky M, et al. Osteoprotegerin abrogated cortical porosity and bone marrow fibrosis in a mouse model of constitutive activation of the PTH/PTHrP receptor. Am J Pathol. 2009;174: 2160-71.

32. Maeda A, Okazaki M, Baron DM, et al. Critical role of parathyroid hormone (PTH) receptor-1 phosphorylation in regulating acute responses to PTH. Proc Natl Acad Sci U S A. 2013;110:5864-9.

33. Liu ES, Martins JS, Raimann A, et al. 1,25-Dihydroxyvitamin D alone improves skeletal growth, microarchitecture, and strength in a murine model of XLH, despite enhanced FGF23 expression. J Bone Miner Res. 2016;31:929-39.

34. Dempster DW, Compston JE, Drezner MK, et al. Standardized nomenclature, symbols, and units for bone histomorphometry: a 2012 update of the report of the ASBMR Histomorphometry Nomenclature Committee. J Bone Miner Res. 2013;28:2-17.

35. Ohishi M, Ono W, Ono N, et al. A novel population of cells expressing both hematopoietic and mesenchymal markers is present in the normal adult bone marrow and is augmented in a murine model of marrow fibrosis. Am J Pathol. 2012;180:811-8.

36. Kuznetsov SA, Riminucci M, Ziran N, et al. The interplay of osteogenesis and hematopoiesis: expression of a constitutively active PTH/PTHrP receptor in osteogenic cells perturbs the establishment of hematopoiesis in bone and of skeletal stem cells in the bone marrow. J Cell Biol. 2004;167:1113-22.

37. Udagawa N, Takahashi N, Yasuda H, et al. Osteoprotegerin produced by osteoblasts is an important regulator in osteoclast development and function. Endocrinology. 2000;141:3478-84.

38. Schipani E, Langman CB, Parfitt AM, et al. Constitutively activated receptors for parathyroid hormone and parathyroid hormonerelated peptide in Jansen's metaphyseal chondrodysplasia. N Engl J Med. 1996;335:708-14.

39. Schipani E, Lanske B, Hunzelman J, et al. Targeted expression of constitutively active receptors for parathyroid hormone and parathyroid hormone-related peptide delays endochondral bone formation and rescues mice that lack parathyroid hormone-related peptide. Proc Natl Acad Sci U S A. 1997:94:13689-94.
40. Ko FC, Karim L, Brooks DJ, Bouxsein ML, Demay MB. Bisphosphonate withdrawal: effects on bone formation and bone resorption in maturing male mice. J Bone Miner Res. 2017;32:814-20.

41. Parasuraman S. Toxicological screening. J Pharmacol Pharmacother. 2011;2:74-9.

42. Calvi LM, Schipani E. The PTH/PTHrP receptor in Jansen's metaphyseal chondrodysplasia. J Endocrinol Invest. 2000;23:545-54.

43. Chagin AS, Kronenberg HM. Role of G-proteins in the differentiation of epiphyseal chondrocytes. J Mol Endocrinol. 2014;53:R39-45.

44. Lanske $B$, Divieti $P$, Kovacs $C S$, et al. The parathyroid hormone (PTH)/PTH-related peptide receptor mediates actions of both ligands in murine bone. Endocrinology. 1999;139:5194-204.

45. Khan SK, Yadav PS, Elliott G, Hu DZ, Xu R, Yang Y. Induced Gnas(R201H) expression from the endogenous Gnas locus causes fibrous dysplasia by up-regulating Wnt/beta-catenin signaling. Proc Natl Acad Sci U S A. 2018;115(3):E418-27.

46. Glukhova A, Draper-Joyce CJ, Sunahara RK, Christopoulos A, Wootten D, Sexton PM. Rules of engagement: GPCRs and G proteins. ACS Pharmacol Transl Sci. 2018;1:73-83.

47. Hjorth S, Ørskov C, Schwartz T. Constitutive activity of glucagon receptor mutants. Mol Endocrinol. 1998;12:78-86.

48. Carter PH, Liu RQ, Foster WR, et al. Discovery of a small molecule antagonist of the parathyroid hormone receptor by using an $\mathrm{N}$ terminal parathyroid hormone peptide probe. Proc Natl Acad Sci U S A. 2007;104:6846-51.

49. McDonald IM, Austin C, Buck IM, et al. Discovery and characterization of novel, potent, non-peptide parathyroid hormone-1 receptor antagonists. J Med Chem. 2007;50:4789-92.

50. Roth $\mathrm{H}$, Fritsche LG, Meier C, et al. Expanding the spectrum of PTH1R mutations in patients with primary failure of tooth eruption. Clin Oral Investig. 2014;18:377-84.

51. Zhang P, Jobert AS, Couvineau A, Silve C. A homozygous inactivating mutation in the parathyroid hormone/parathyroid hormone-related peptide receptor causing Blomstrand chondrodysplasia. J Clin Endocrinol Metab. 1998;83:3365-8.

52. O'Brien CA, Plotkin LI, Galli C, et al. Control of bone mass and remodeling by PTH receptor signaling in osteocytes. PLoS One. 2008;3: e2942.

53. Bellido T, Ali AA, Gubrij I, et al. Chronic elevation of parathyroid hormone in mice reduces expression of sclerostin by osteocytes: a novel mechanism for hormonal control of osteoblastogenesis. Endocrinology. 2005;146:4577-83. 